Mahmoud A. El-Sharief, Using value stream mapping for lean manufacturing implementation: cement sacks factory as an industrial case study, pp.2190 - 2212

\title{
USING VALUE STREAM MAPPING FOR LEAN MANUFACTURING IMPLEMENTATION: CEMENT SACKS FACTORY AS AN INDUSTRIAL CASE STUDY
}

\author{
Mahmoud A. El-Sharief \\ Mechanical Engineering Department - Faculty of Engineering, Assiut University, 71516 Assiut \\ E-Mail address: msharif@assiut.edu.eg
}

Received 9 November 2013; accepted 25 November 2013

\begin{abstract}
Lean manufacturing is a production system, which was first developed by Toyota Production Systems (TPSs) to reduce wastes while improving the operational and environmental performance of manufacturing and industrial businesses. While the global industrial market suffers from gnarled competition, lean manufacturing philosophy is providing an effective methodology to reduce cost and maximize profit. In addition, the market no longer accepts waste caused by out of control production or inefficient processes. A commitment to quality and lean operations will result in quality improvement, waste elimination and reduction in time and costs.

Value stream mappings (VSMs), a lean manufacturing tool, which originated from the Toyota Production Systems (TPSs), is known as "material and information flow mapping." This mapping tool uses the techniques of lean manufacturing to analyze and evaluate certain work processes in a manufacturing operation. This tool is used primarily to identify, demonstrate and decrease waste, as well as create flow in the manufacturing process. VSM can be created merely using paper and pencil; however, more advanced maps are created using Microsoft Visio as well as Microsoft Excel. This paper describes practical implementation strategies for using lean manufacturing and an industrial case study(Cement Sacks Factory) is included. After lean manufacturing methodology has been applied to the case, results are produced as Cement Sacks Factory process efficiency is raised by $4.31 \%$ and the TAKT time is reduced about $56 \%$.
\end{abstract}

Keywords: Lean Manufacturing; Value Stream Mapping; Waste elimination; Facility layout; Case study

\section{Introduction}

The critical starting point for lean thinking is value. As stated Womack et al. [1] value can only be defined by the ultimate customer. Moreover, it is only meaningful when expressed in terms of a specific product (a good or a service, and often both at once)which meets the customer's needs at a specific price at a specific time. Value is created by the producer. From the customer's standpoint, this is why producers exist.

With going on years, world has achieved great steps in industrial life to people, thus made countries to compete with them in grossing their industrial fleet. Therefore, industrial associations expanded to include many sectors in the same association. With competition between power centers in world and war between them, industrial association has begun to find systems to manage its big factories. Hence, many systems appeared, such as "lean", "six sigma " and " lean six sigma ".

Journal of Engineering Sciences, Assiut University, Faculty of Engineering, Vol. 41, No. 6, November, 2013, E-mail address: jes@aun.edu.eg 
Mahmoud A. El-Sharief, Using value stream mapping for lean manufacturing implementation: cement sacks factory as an industrial case study, pp. 2190 - 2212

\subsection{Lean manufacturing system}

Lean Manufacturing is the systematic elimination of waste from all aspects of an organization's operations, where waste is viewed as any use or loss of resources that does not lead directly to creating the product or service a customer wants when they want it. In many industrial processes, such non-value added activity could comprise more than 90 percent of a factory's total activity [1].

Lean manufacturing is the processes, techniques, strategies and initiatives being implemented by companies around the world that aim to reduce unnecessary and unproductive tasks, activities and behaviors in the work environment. In other word, lean manufacturing is implemented in order to reduce waste and improve the organization production and morale.

There are many tools and techniques in lean manufacturing that can be implemented but the selection of effective lean tool, and technique in lean manufacturing is hard to choose. Wrong decision will affect the waste and time. Lean thinking is a highly involved method of managing an organization to improve the productivity, efficiency, and quality of products and services.

\subsection{Lean manufacturing benefits}

T. MELTON [2] stated the benefits of lean manufacturing are:

- Help to produce business outputs as fast as possible.

- Convert a business enquiry to a finished output; then it can hold less row material and finished stock inventory.

- Hold lower inventory levels means need less cash to run the business.

- Able to produce work faster.

- Can do more with the same resources (machinery, people).

- Can complete work faster than competitors.

- Reduce the cash required for your business attractive.

\subsection{More common practices of lean manufacturing}

A few of the more common practices of the lean manufacturing are:

- Just In Time: Producing only what is needed, when it is needed, and with the needed quantities; reducing work-in-process inventory.

- Kanban: A card that signals production of a set quantity of goods once that number of goods has been used by a customer process.

- Production leveling (or heijunka): Spreading production evenly over time; reducing batch sizes to one.

- Setup time reduction: Reducing the time to changeover between producing different products; required leveling production.

- Standardized work: Documented, detailed work procedures religiously followed by everyone doing the job such that the work is performed the same way every time.

Journal of Engineering Sciences, Assiut University, Faculty of Engineering, Vol. 41, No. 6, November, 2013, E-mail address: jes@aun.edu.eg 
Mahmoud A. El-Sharief, Using value stream mapping for lean manufacturing implementation: cement sacks factory as an industrial case study, pp. 2190 - 2212

- Multi-skilled workers: Workers trained in multiple job tasks so work can be assigned flexibly to balance the line dynamically.

\subsection{Identification and elimination of waste}

The philosophy of identification and elimination of the waste is:

- The central theme of a lean manufacturing production system.

- A dynamic and constantly improving process dependent upon understanding and involvement by all employees.

- Successful implementation that requires all employees must be trained to identify and eliminate waste from their work.

- Waste exists in all work and at all levels in the organization.

\subsection{Types of waste}

There are seven types of wastes [1]:

- Over-production, producing more than needed, and/or producing faster than needed.

- Wait time, idle time that is produced when two dependent variables are not fully synchronized.

- Transportation, any material movement that does not directly support a Lean Manufacturing System.

- Processing, effort that adds no value to a product or service.

- Inventory, any supply in excess of process requirements necessary to produce goods or services Just in Time.

- Motion, any movement of people that does not contribute added value to the product or service.

- Reworks or Corrections, repair of a product or service to fulfill customer requirements

\section{Value Stream Mapping}

Jim Womack et al. [3] presented that a Value Stream Mapping (VSM) is a collection of all actions value added as well as non-value added that are required to bring a product or a group of products that use the same resources through the main flows, from raw material to the customers. These actions are those in the overall supply chain including both information and operation flow which are the core of any successful lean operation. Value stream mapping is a special type of flow chart that uses numbers and symbols known as "the language of lean" to improve the flow of material and information.

\subsection{Value stream mapping benefits}

Ulf K. Teichgraeber et al [4] stated that there is a need to understand the entire manufacturing system in order to create VSM and gain maximum benefits, which are:

Journal of Engineering Sciences, Assiut University, Faculty of Engineering, Vol. 41, No. 6, November, 2013, E-mail address: jes@aun.edu.eg 
Mahmoud A. El-Sharief, Using value stream mapping for lean manufacturing implementation: cement sacks factory as an industrial case study, pp. 2190 - 2212

- In order to visually display where waste occurs in the process and to distinction between values add and non-value add activities (waste), a value stream map (VSM) is drawn because the main principle of lean manufacturing is to reduce waste in an operation, such as long lead times, defects and material waste.

- Shows the linkage between material and information flow of a product

- Identifies all types of waste in the value stream and take steps to try eliminating them.

- Once the current state VSM is created, it becomes the baseline for improvement and for the creation of a future state value stream mapping FSVSM. The FSVSM can then be used as a world class manufacturing implementation road map.

\subsection{VSM Creation}

The procedure of the VSM creation is:

\section{The Current State Value Stream Map}

- $\quad$ Select the product family that will be mapped

- Decide what the goal for improvement will be

- Form a team to collect data and map the selected value stream

- Walk the flow and collect data on the value stream

- Value Stream Map terminology

- Value stream map standard symbols

- Draw a map of the value stream

\section{Analysis the Current conditions}

- Identify value added and waste

- Choosing appropriate waste reduction methods and reconfigure process to eliminate waste and maximize value

\section{Take actions and create the Future State Value Stream Map.}

\subsubsection{The current state value stream map}

\subsubsection{Select the product family that will be mapped}

Value stream maps are created for a single product, or a family of products. A family is a group of products with similar routings, similar process times, and customers with similar needs and demand rates. 'Similar' means that while there may be some variation, it is recognizable that all members of the group have the same set of core operations. Products may vary by color, size, or one or two steps in the production process. H.J. Warnecke et al. [5] presented the reason for concentrating on a family of products is that lean improvements such as cells and kanban systems only work well if all products in the stream are similar in process times and routings.

Journal of Engineering Sciences, Assiut University, Faculty of Engineering, Vol. 41, No. 6, November, 2013, E-mail address: jes@aun.edu.eg 
Mahmoud A. El-Sharief, Using value stream mapping for lean manufacturing implementation: cement sacks factory as an industrial case study, pp. 2190 - 2212

\subsubsection{Decide on the goal for improvement}

There are different opinions about what the goal should be. First opinion for Advocates of the TPS style of lean manufacturing will claim that production at takttime is the only acceptable goal of the improvement process. Second opinion is that takttime is an outcome, not a design parameter. Whether the goal is to reduce cost by eliminating waste, or to produce in time with customer demand, value stream mapping is an essential tool, and it is independent of anyone production philosophy.

\subsubsection{Form the value stream mapping team}

Value stream mapping is the best done by a team in a workshop format. This is because few people really understand the entire value stream, or have the knowledge to anticipate the impacts of specific changes to it. A team with a variety of members is therefore required.

\subsubsection{Walk the flow}

The team members should have a form for gathering data on each step (including work centers, queues, raw materials arrival, shipping to the customer, and operators).

\subsubsection{VSM terminologies}

- Value-added activities: An activity that transforms or shapes material or information, the customer wants it and it is done right the first time.

- Non value added-needed activities: Activities which causing no value to be created but which cannot be eliminated based on current state of technology or thinking required (regulatory, customer mandate, legal).

- Non value-added activities: Activities that consumes resources but create no value in the eyes of the customer.

- Cycle time: Cycle time is the time required to execute activities in a process (including value-added and non-value added time)

- Takt time: Measure of customer demand - how much is required in the time available

Takt Time = available time / time customer demand rate for available time

- The information flow: Indicates how each process will know what to make. The information flow is drawn on the upper portion of the map. The information flow is drawn from right to left on the map and is connected to the material flow previously drawn.

- Time line: After the completion of the map, a timeline is drawn below the process boxes to indicate the production lead-time and value added time.

- Production lead-time: The time that a particular product spends on the shop floor from its arrival until its completion.

- Value added time: This time represents the sum of the processing times for each process.

- $\quad$ Process cycle efficiency $=$ Value added time/ total cycle time

Journal of Engineering Sciences, Assiut University, Faculty of Engineering, Vol. 41, No. 6, November, 2013, E-mail address: jes@aun.edu.eg 
Mahmoud A. El-Sharief, Using value stream mapping for lean manufacturing implementation: cement sacks factory as an industrial case study, pp. 2190 - 2212

- Value Stream Map and Selected Standard Icons:VSM symbols is not standardized and there are many variations. Here are the most common symbols.

\subsubsection{VSM process symbols}

Value stream map uses special symbols to represent where there is waste in manufacturing processes and to help find ways to eliminate that waste.

\subsubsection{Draw the current state map}

The current state map is simply a set of connected operations and queues starting with a supplier and ending with a customer. After the data collection is complete, all of the data can be collected in a single spreadsheet or transferred directly to the value stream map from each team member's notes as follows:

- Draw customer, supplier and production control icons.

- Enter customer requirement.

- Calculate takt time.

- Draw outbound shipping icon and truck with delivery frequency.

- Draw in bound shipping icon and truck with delivery frequency.

- Add process box, in sequence, left to right.

- Add collected data box below.

- Add communication and information flow arrows.

- Obtain process attributes. Add to data box.

- Add operator symbols.

- Add inventory locations and level in days of demand and graph at bottom.

- Add push and pull icons.

- Add other information.

- Add working hours.

- Add value and non-values add time.

- Calculate total value and non-value add times.

\subsubsection{Analysis the current conditions}

\subsubsection{Identify value added and waste}

Value stream mapping is a process designed to reduce lead-time to make product flow and to eliminate waste (non-value added operations or activities). All for purpose of meeting customer demand at the lowest cost and with the highest quality[6]. Lean thinking relies on recognizing the "seven wastes" over-production, over-processing, inventory, motion, scrap, waiting and transportation. With simulation, it is easy to avoid the traditional problem of eliminating waste at an operation where there is no net gain [7]. That is because the revised system's performance can be compared to the current state to see the impact of the proposed change.

Journal of Engineering Sciences, Assiut University, Faculty of Engineering, Vol. 41, No. 6, November, 2013,E-mail address: jes@aun.edu.eg 
Mahmoud A. El-Sharief, Using value stream mapping for lean manufacturing implementation: cement sacks factory as an industrial case study, pp. 2190 - 2212

\subsubsection{Choosing appropriate waste reduction methods and reconfigure process to eliminate waste and maximize value}

Matthias Holweg et al. [8] stated that there are many waste elimination methods that can be applied in a given situation, but selecting the appropriate method is not easy. Consideration must be made of cost disruption to other product families and parts of the production system, operator skills, maintenance, reliability, space and so forth.

\subsubsection{Take actions and create the future state value stream map}

The future state map is nothing more than an implementation plan that highlights what kind of lean tools are needed to eliminate the waste, and where they are needed in the product value stream. Creating a future state map is done through answering a set of questions concerning issues related to building of the future state map and technical implementation related to the use of lean tools. Based on the answers to these questions one should mark the future state ideas directly on the future state map. After creating the future state map, the last step is to carry it out by trying to implement the different ideas generated by the future state map on the actual value stream.

\subsection{The lean facility layout}

Layout is an integral part of a Lean manufacturing strategy. Meaningful restructuring requires corresponding physical changes in the layout. Flow is one of the main five concepts of lean manufacturing, but in order to achieve smooth flow important decisions must be taken and that is to plan and design a layout that is integrated to other concepts of lean along with the flow.

Facility layout decision is based on criteria aimed at creating an effective and efficient workflow and high standard production. Conversely, a layout re-design can be the catalyst for re-structuring. A layout project properly done can demonstrate the need for change to an organization reluctant to tear itself apart and rebuild. Therefore, requirements for effective layout are:

- Minimize material handling costs

- Utilize space efficiently

- Utilize labor efficiently

- Eliminate bottlenecks

- Facilitate communication and interaction between workers, between workers and their supervisors, or between workers and customers.

- Reduce manufacturing cycle time and customer service time

- Eliminate wasted or redundant movement

- Facilitate the entry, exit, and placement of material, products, and people

- Incorporate safety and security measures; Promote product and service quality

- Encourage proper maintenance activities

- Provide a visual control of operations or activities

- Provide flexibility to adapt to changing conditions

Journal of Engineering Sciences, Assiut University, Faculty of Engineering, Vol. 41, No. 6, November, 2013, E-mail address: jes@aun.edu.eg 
Mahmoud A. El-Sharief, Using value stream mapping for lean manufacturing implementation: cement sacks factory as an industrial case study, pp. 2190 - 2212

\subsection{Lean factory design}

A lean plant/shop floor layout has significant impact on the organization's performance. Material and information flow is organized and streamlined. A lean plant layout is an effective way to improve profitability and throughput while increasing safety [9]. The elimination of wasted movement and implementing line balancing can significantly reduce costs and reduce cycle time to provide speed of delivery and improved throughput.

\subsection{Process flow analysis}

Figure 1 shows an example for process flow analysis, which allows visualization of the movement of people or materials. This can quickly lead to an understanding of where inefficiencies exist and how to eliminate them. It is critical to layout work in the order it will occur to the greatest extent possible, in order to eliminate the waste of movement.

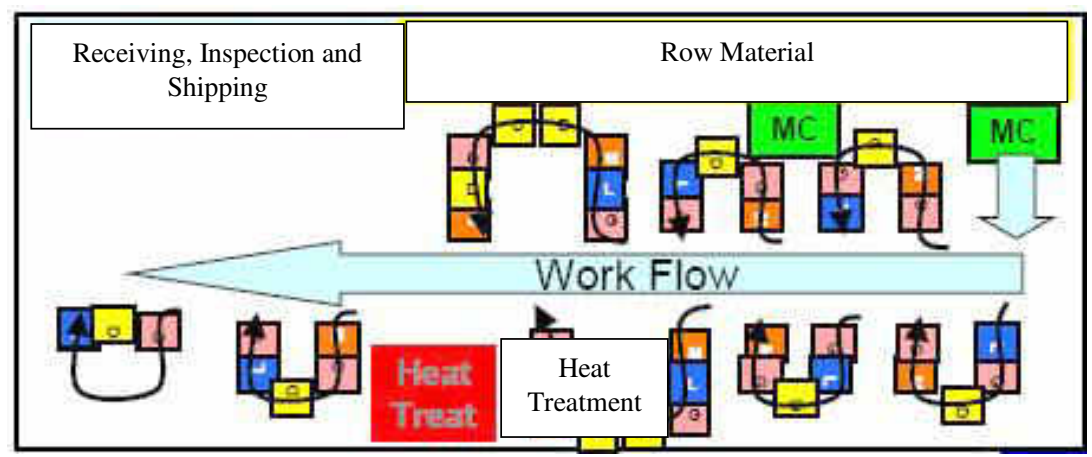

Fig. 1 Processes flow

\section{Cement Sacks Factory}

\subsection{Cement sacks factory information}

- $\quad$ Name: Cement sacks factory

- Area: $6250 \mathrm{~m}^{2}$

- No of products: $2 X$ (for itself\& other factories)

- Layout: Figure 3 represents the cement sacks factory layout

\subsection{Sequence of production processes}

Figures 2 to 11 show the sequence of production processes in the Cement Sacks factory case study. 
Mahmoud A. El-Sharief, Using value stream mapping for lean manufacturing implementation: cement sacks factory as an industrial case study, pp. 2190 - 2212

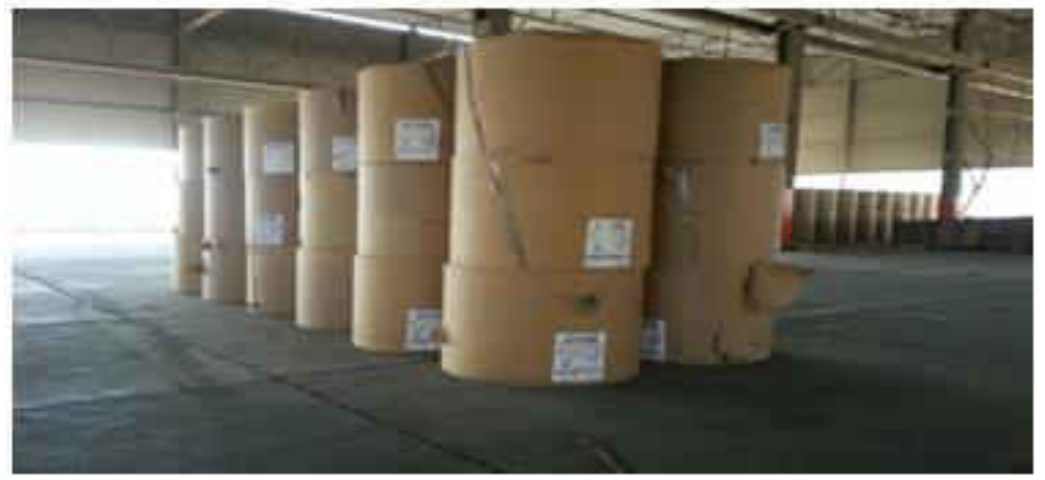

Fig. 2.Transport the craft paper roller with the fork lift

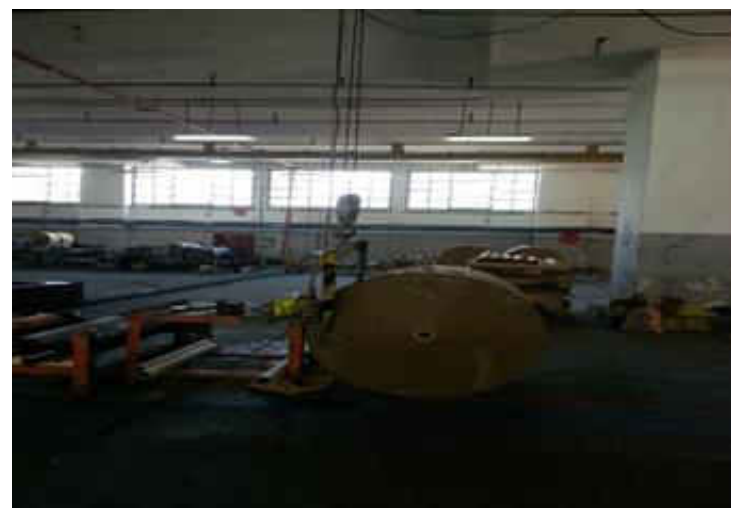

Fig. 3. Set the craft paper roller in the beginning of the production line

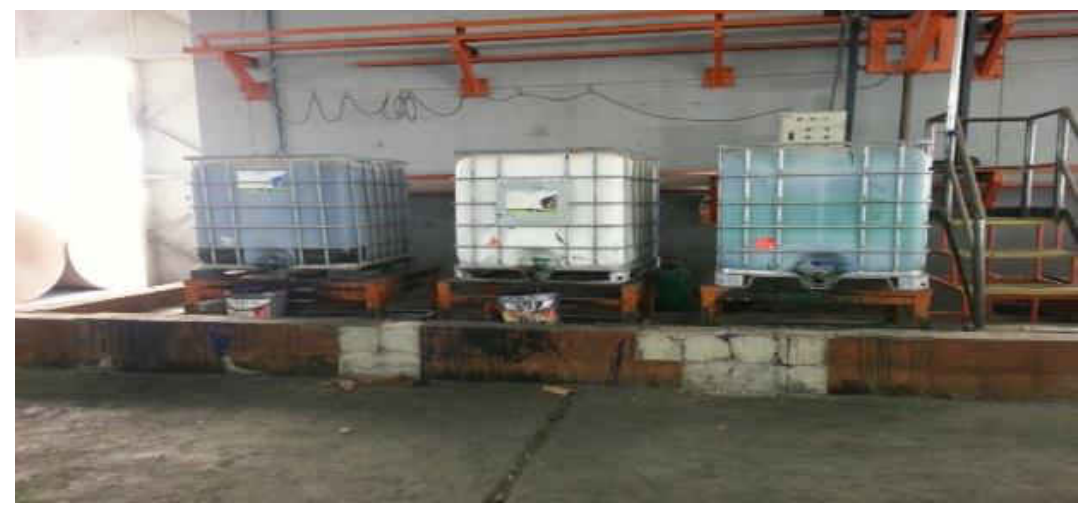

Fig. 4.Get ink from ink tank (printing)

Journal of Engineering Sciences, Assiut University, Faculty of Engineering, Vol. 41, No. 6, November, 2013, E-mail address: jes@aun.edu.eg 
Mahmoud A. El-Sharief, Using value stream mapping for lean manufacturing implementation: cement sacks factory as an industrial case study, pp. 2190 - 2212

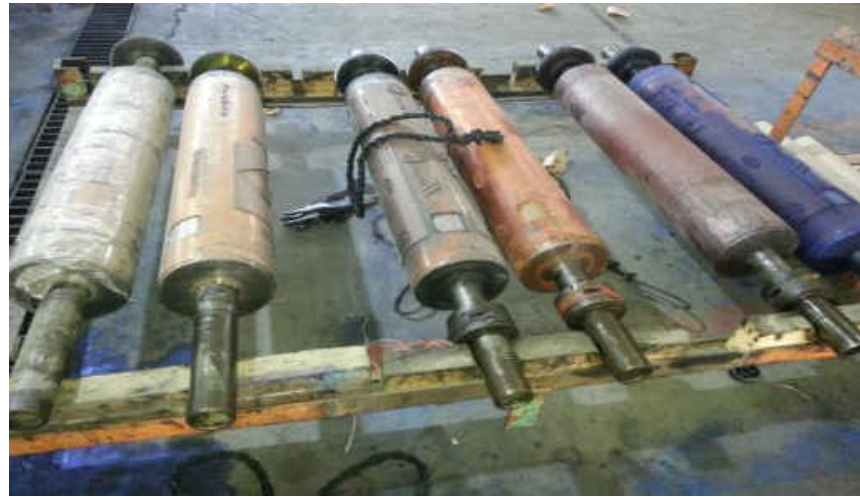

Fig. 5. Select the suitable Crile

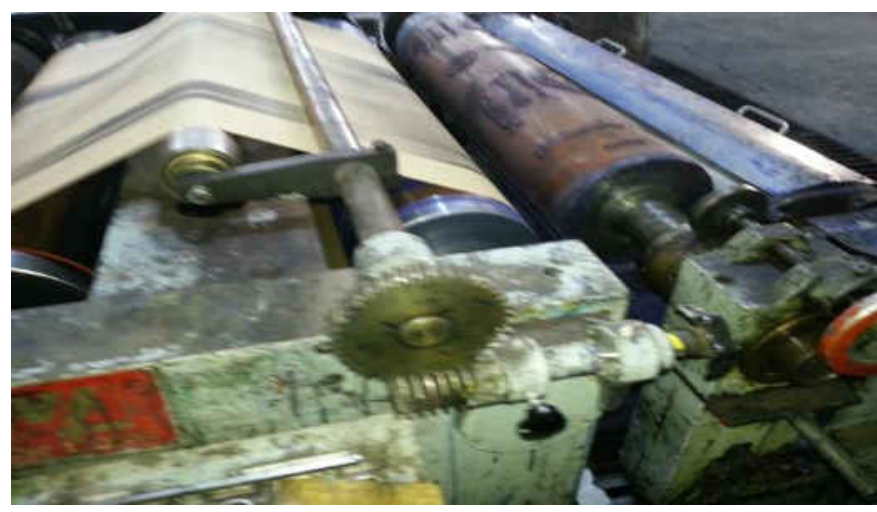

Fig. 6.Installation of the Crile

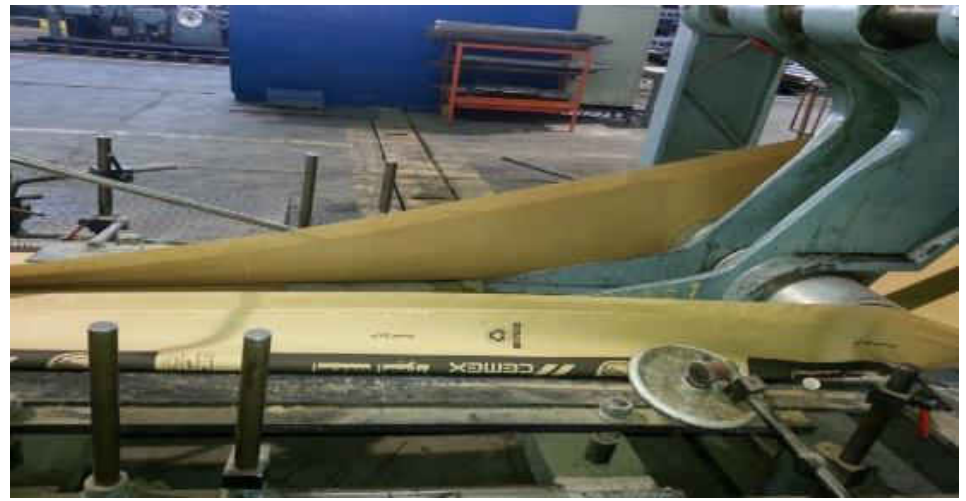

Fig. 7. First steps in sacks forming (overlapping)

Journal of Engineering Sciences, Assiut University, Faculty of Engineering, Vol. 41, No. 6, November, 2013, E-mail address: jes@aun.edu.eg 
Mahmoud A. El-Sharief, Using value stream mapping for lean manufacturing implementation: cement sacks factory as an industrial case study, pp. 2190 - 2212

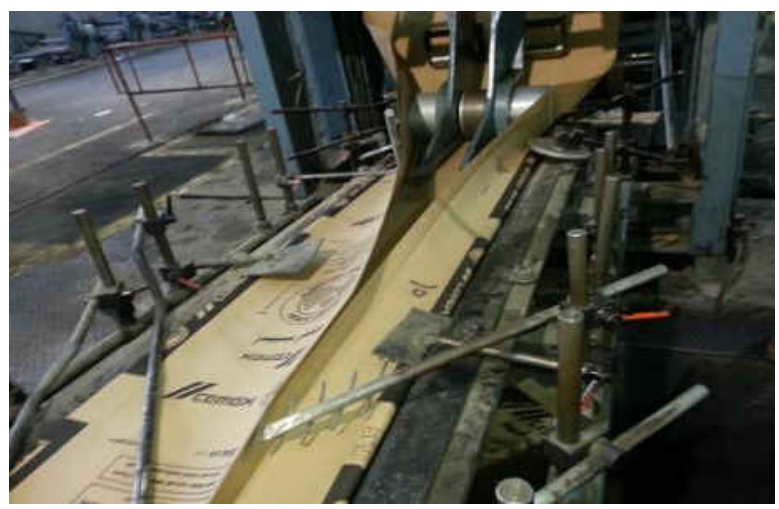

Fig. 8. Guides to improve the overlapping process and movements

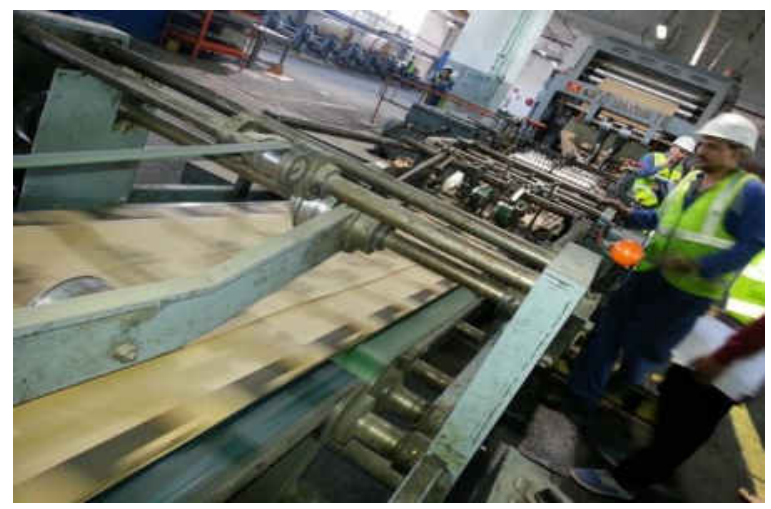

Fig. 9. Sacks stick (tubing)

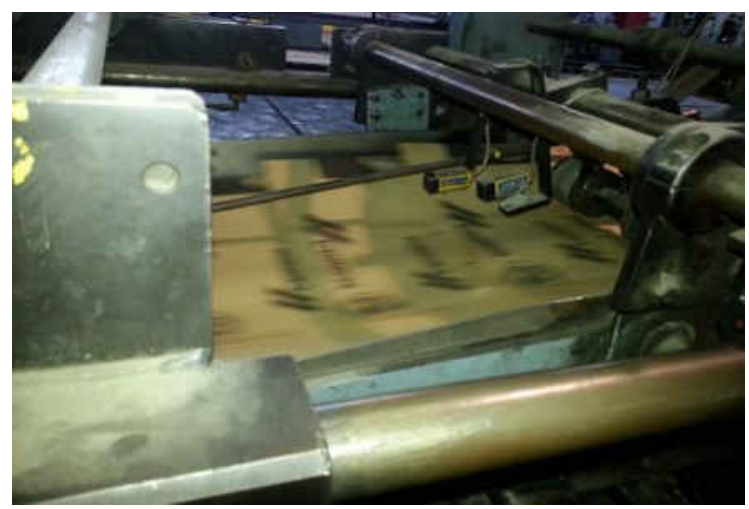

Fig. 10. Preparing for the final sacks (separation)

Journal of Engineering Sciences, Assiut University, Faculty of Engineering, Vol. 41, No. 6, November, 2013, E-mail address: jes@aun.edu.eg 
Mahmoud A. El-Sharief, Using value stream mapping for lean manufacturing implementation: cement sacks factory as an industrial case study, pp. 2190 - 2212

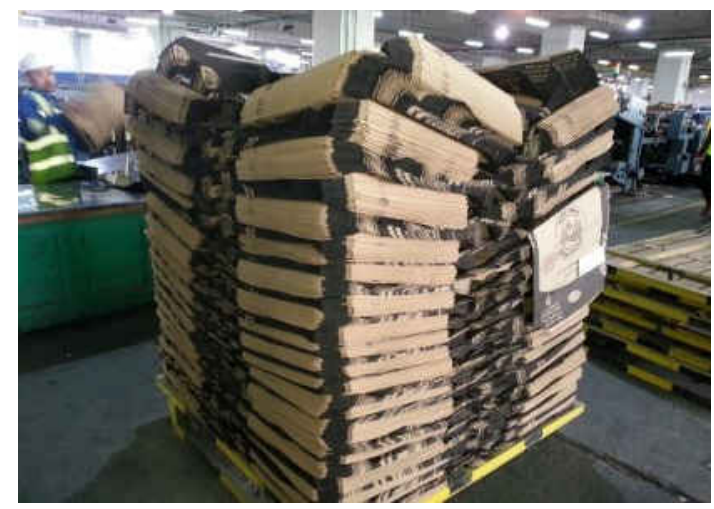

Fig. 11. Final product ready to store

\subsection{Requirements of the production line processes}

\section{Table 1.}

Processes requirements

\begin{tabular}{|c|c|c|c|c|c|}
\hline Step & $\begin{array}{c}\text { Process } \\
\text { Description }\end{array}$ & No. of Worker & $\begin{array}{c}\text { Distance } \\
(\mathbf{m})\end{array}$ & $\begin{array}{c}\text { Task time } \\
(\mathbf{m i n})\end{array}$ & $\begin{array}{c}\text { Wait time } \\
(\mathbf{m i n})\end{array}$ \\
\hline 1 & Remove cover & 1 & 12.5 & $2: 00$ & 0 \\
\hline 2 & printing & 1 same worker & 12.5 & $00: 05$ & $02: 00$ \\
\hline 3 & overlapping & 1 same worker & 12.5 & $00: 05$ & 0 \\
\hline 4 & Guides & 1 same worker & 12.5 & $00: 05$ & 0 \\
\hline 5 & Glutinous & 1 same worker & 12.5 & $00: 05$ & 0 \\
\hline 6 & Tubing & 1 same worker & 12.5 & $00: 05$ & 0 \\
\hline 7 & separation & 1 same worker & 12.5 & $00: 05$ & 0 \\
\hline
\end{tabular}

\subsection{VSM of the Cement Sacks Factory}

As reported before, VSM is the tool of lean manufacturing, "Simple Follow product's production path from customer to supplier and carefully draw a visual representation of every process in the material and information flow". VSM is all the actions (both value added and non-value added currently required to bring a product through the main flows essential to every product. Figure 12 presents the current layout of the Cement Sacks factory. 
Mahmoud A. El-Sharief, Using value stream mapping for lean manufacturing implementation: cement sacks factory as an industrial case study, pp. 2190 - 2212

\subsubsection{Current VSM}

Figure 13 presents the current VSM of the Cement Sacks factory.

\section{VSM Data Set:}

- Product flow unit of 10,000-cement packs.

- Handling using two forklifts with speed $=47 \mathrm{~m} / \mathrm{min}$ each.

- Coding time for one 5,000 sacks pallet $=1 \mathrm{~min}$.

\section{Product:}

Cement packs consist of:

- Craft paper

- Glue

- Ink

\section{Customer Requirements:}

- Pallet=5000 packs.

\section{Working Time:}

- Shift time $=6.75 \mathrm{hr}$.

- Break time $=1.25 \mathrm{hr}$.

\section{Manufacturing Process:}

Manufacturing processes for a sample consists of 10000 packs are shown in table 2 . 


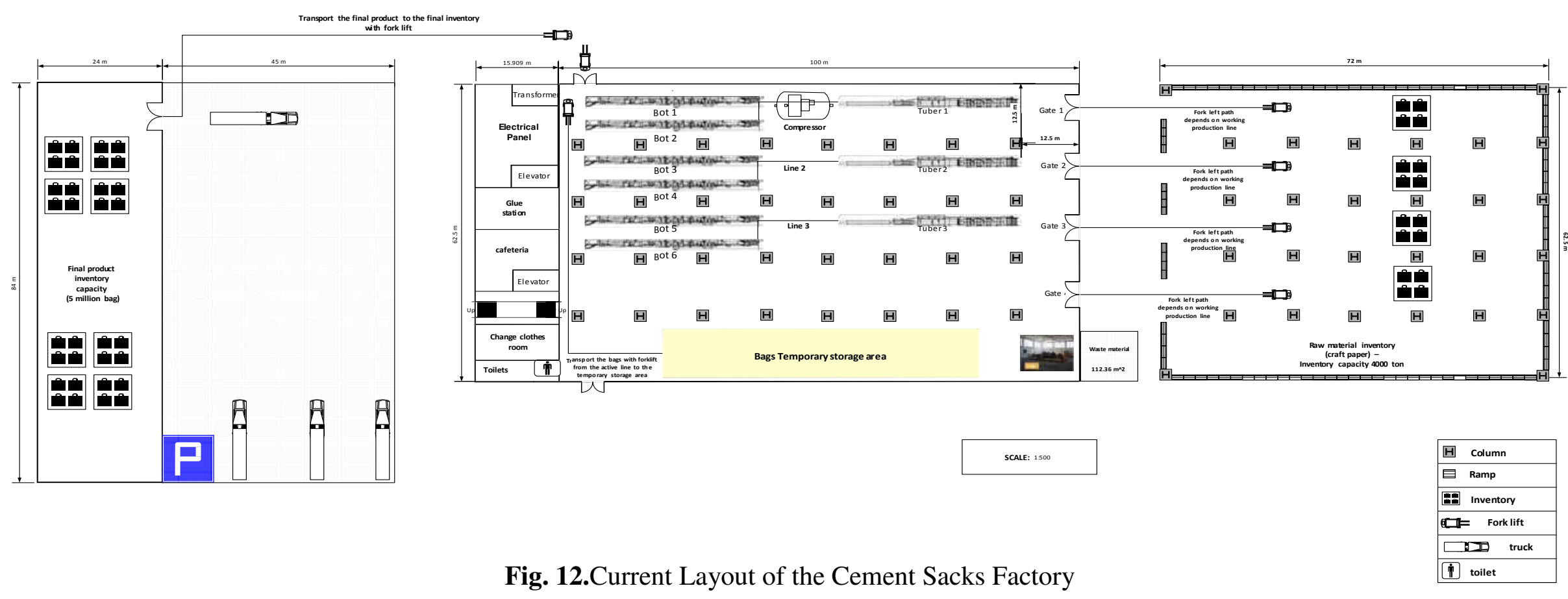




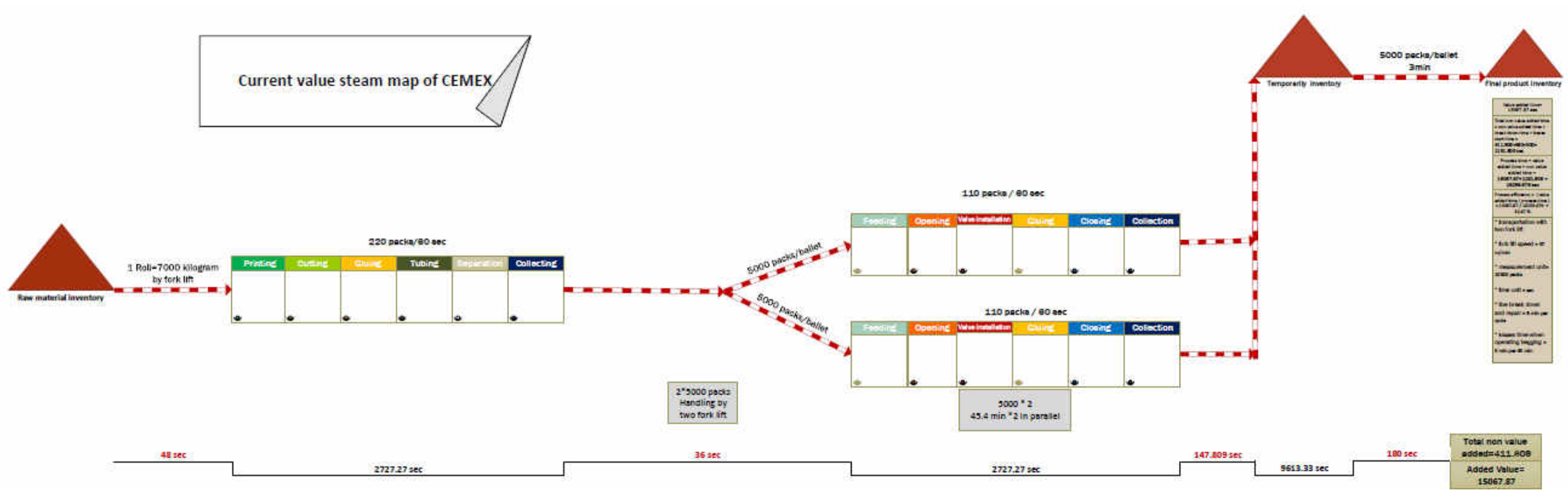

Fig. 13. Current VSM of the Cement Sacks Factory 
Mahmoud A. El-Sharief, Using value stream mapping for lean manufacturing implementation: cement sacks factory as an industrial case study, pp.2190 - 2212

Table 2.

Value and non-value added times of the manufacturing processes for the cement sacks factory case study

\begin{tabular}{|c|c|c|}
\hline Step & Description & Time \\
\hline $\begin{array}{l}\text { Handling of raw } \\
\text { material }\end{array}$ & $\begin{array}{l}\text { From raw material inventory to } \\
\text { the production line by using } \\
\text { forklift. }\end{array}$ & Non value added time $=48 \mathrm{sec}$ \\
\hline $\begin{array}{ll}- & \text { First stage of } \\
\text { production: } \\
- & \text { Manufacturing primary } \\
\text { product(size = } 2 \text { ballet) }\end{array}$ & $\begin{array}{l}\text { It includes the following } \\
\text { processes: } \\
\text { - Printing } \\
\text { - Cutting } \\
\text { - } \text { Glowing } \\
\text { - Tubing } \\
\text { - Separation } \\
\text { - } \quad \text { Collecting }\end{array}$ & Value added time $=2727.27 \mathrm{sec}$ \\
\hline $\begin{array}{l}\text { Handling primary } \\
\text { product to the final } \\
\text { production steps }\end{array}$ & $\begin{array}{l}\text { By using two forklifts to handle } \\
\text { the two ballets in the same time. } \\
\text { This activity time includes: } \\
\text { - The time for set the last } 220 \\
\text { packs on the pallet. } \\
\text { - Forklift down time. } \\
\text { - Forklifts time to handle } \\
\text { pallets between the two } \\
\text { production stages. }\end{array}$ & Non value added time $=36 \mathrm{sec}$ \\
\hline $\begin{array}{ll}\text { - } & \text { Second stage of } \\
\text { production: } \\
\text { - } & \text { Final manufacturing } \\
\text { steps }\end{array}$ & $\begin{array}{l}\text { It includes the following } \\
\text { processes: } \\
\text { - Feeding } \\
\text { - Opening } \\
\text { - } \quad \text { Valve installation } \\
\text { - Gluing } \\
\text { - Closing } \\
\text { - Collection }\end{array}$ & $\begin{array}{l}\text { Value added time }=2727.27 \\
\text { sec }\end{array}$ \\
\hline
\end{tabular}

Journal of Engineering Sciences, Assiut University, Faculty of Engineering, Vol. 41, No. 6, November, 2013,E-mail address: jes@aun.edu.eg 
Mahmoud A. El-Sharief, Using value stream mapping for lean manufacturing implementation: cement sacks factory as an industrial case study, pp. 2190 - 2212

\begin{tabular}{|c|c|c|}
\hline Step & Description & Time \\
\hline $\begin{array}{l}\text { Handling final product } \\
\text { to the temporary } \\
\text { inventory }\end{array}$ & $\begin{array}{l}\text { The time for this process } \\
\text { includes: } \\
\text { - The time for set the last } 220 \\
\text { packs on the pallet. } \\
\text { - Fork lifts caring and down } \\
\text { time. } \\
\text { - Fork lifts time to transfer the } \\
\text { pallets. } \\
\text { - Coding time. }\end{array}$ & $\begin{array}{l}\text { Non } \quad \text { value } \\
\text { time=147.809 } \mathrm{sec}\end{array}$ \\
\hline - Temporary inventory & $\begin{array}{l}\text { This step is taken for sacks to } \\
\text { drying glue }\end{array}$ & Value added time $=9613.33 \mathrm{sec}$ \\
\hline $\begin{array}{l}\text { Handling pallets to the } \\
\text { final product inventory }\end{array}$ & $\begin{array}{l}\text { This uses two forklifts to handle } \\
\text { the two pallets }\end{array}$ & Non value added time $=180 \mathrm{sec}$ \\
\hline - Final product inventory & Final sacks storage & Out of process description \\
\hline
\end{tabular}

\subsubsection{Current process efficiency}

- Break down and repairing time for one cycle $=8 / 45=0.178 \mathrm{~min}$.

- Total value add time $=15067.87 \mathrm{sec}$.

- Total non-value added time = non-value add time +break down time + losses time.

- $\quad=411.809+480+300$.

- $\quad=1191.809 \mathrm{sec}$.

- $\quad$ Process time $=15067.87+1191.809=16259.679 \mathrm{sec}$.

- $\quad$ Process efficiency $=15067.87 / 16259.679=92.67 \%$.

\subsubsection{Modified value stream mapping}

These value stream maps show the effect of applying lean thinking on the efficiency of the production lines for the Cement Sacks Factory as shown in table 3.Figures 14 and 15 show the modified layout and VSM respectively of the Cement Sacks Factory.

Journal of Engineering Sciences, Assiut University, Faculty of Engineering, Vol. 41, No. 6, November, 2013,E-mailaddress: jes@aun.edu.eg 
Mahmoud A. El-Sharief, Using value stream mapping for lean manufacturing implementation: cement sacks factory as an industrial case study, pp. 2190 - 2212

\section{Table 3.}

\section{Impact of the lean thinking on the Cement Sacks Factory}

\begin{tabular}{|c|c|c|}
\hline Modification & Reasons & Result \\
\hline $\begin{array}{l}\text { 1- Handling between } \\
\text { tuberand bottomers } \\
\text { using roller conveyor } \\
\text { rather than using fork } \\
\text { lifts }\end{array}$ & $\begin{array}{l}\text { The forklift cost }=100 \text { (L.E / day) } \\
\text { and these is huge cost add to the cost } \\
\text { of the product. } \\
\text { The cost of the conveyor will be } \\
\text { illustrated in a budget study later. }\end{array}$ & $\begin{array}{l}\text { - Reduce the handling time to be } \\
=18.75 \mathrm{sec} \text { instead of } 36 \mathrm{sec} \text {. } \\
\text { - Reduce the handling cost add to } \\
\text { the production cost. }\end{array}$ \\
\hline $\begin{array}{l}\text { 2- Change factory door } \\
\text { position and this is } \\
\text { shown in the modified } \\
\text { layout. }\end{array}$ & The forklift way is very long & $\begin{array}{l}\text { - Reduce the forklift way from the } \\
\text { temporary inventory to the final } \\
\text { product inventory and reach the } \\
\text { maximum benefit of the forklift. } \\
\text { Reduce time required for handling } \\
\text { between temporary and final } \\
\text { product inventory to be }=100.85 \\
\text { sec instead of } 180 \mathrm{sec} \text {. }\end{array}$ \\
\hline $\begin{array}{l}\text { 3- Fill two pallets with } \\
10000 \text { packs ready to } \\
\text { use in the next work } \\
\text { day }\end{array}$ & $\begin{array}{l}\text { The bottomer lines stop working for } 45 \\
\text { min at the start of the shift until the tuber } \\
\text { working for } 45 \mathrm{~min} \text { to produce the two } \\
\text { pallets. }\end{array}$ & $\begin{array}{l}\text { The two stages of production work } \\
\text { together. }\end{array}$ \\
\hline
\end{tabular}

\section{Conveyor specifications and designation}

- Conveyor length $=12$ meter

- Conveyor width $=4$ meter

- Conveyor velocity under zero load $=120 \mathrm{~m} / \mathrm{min}$

- Conveyor velocity under $\max$. load $=40 \mathrm{~m} / \mathrm{min}$

- Conveyor max load $=15$ ton

\section{Cost review for roller conveyor}

Table 4 shows budget statement (this budget will show the cost of three motorized conveyors)

\section{Table 4.}

Cost review for roller conveyor

\begin{tabular}{|c|c|c|}
\hline Components & Number & Cost per three units \\
\hline Roller conveyor & 3 & 15000 L.E \\
\hline Chain belt & 3 & 600 L.E \\
\hline 15 hp. Driver motor & 3 & 190000 L.E \\
\hline & & Total cost $=205600$ L.E \\
\hline
\end{tabular}

Journal of Engineering Sciences, Assiut University, Faculty of Engineering, Vol. 41, No. 6, November, 2013,E-mail address: jes@aun.edu.eg 
Mahmoud A. El-Sharief, Using value stream mapping for lean manufacturing implementation: cement sacks factory as an industrial case study, pp. 2190 - 2212

\section{Income statement}

- After applying this modification, the handling time between tubers and bottomers, will be reduced by $17.25 \mathrm{sec}$.

- The production time for one cement bag $=0.655 \mathrm{sec}$.

- This will show that in the $17.2 \mathrm{sec}$. will produce 27 bag

- The net profit for one bag =0.2 L.E

- The daily bag production 90000 bags

- $\quad$ The daily net profit $=90000 * 0.2=18000$ L.E

\section{Cach flow statement}

After reviewing budget and income statement, the total cost $=205600 \mathrm{~L}$.E and capital recovery rate $=205600 / 18000=12$ days

\section{Modification results}

The non-value added time will be reduced to $=315.409 \mathrm{sec}$ instead of $1191.809 \mathrm{sec}$. Therefore the efficiency of the production line cycle will be increased to $=94.98 \%$ instead of $92.67 \%$. 


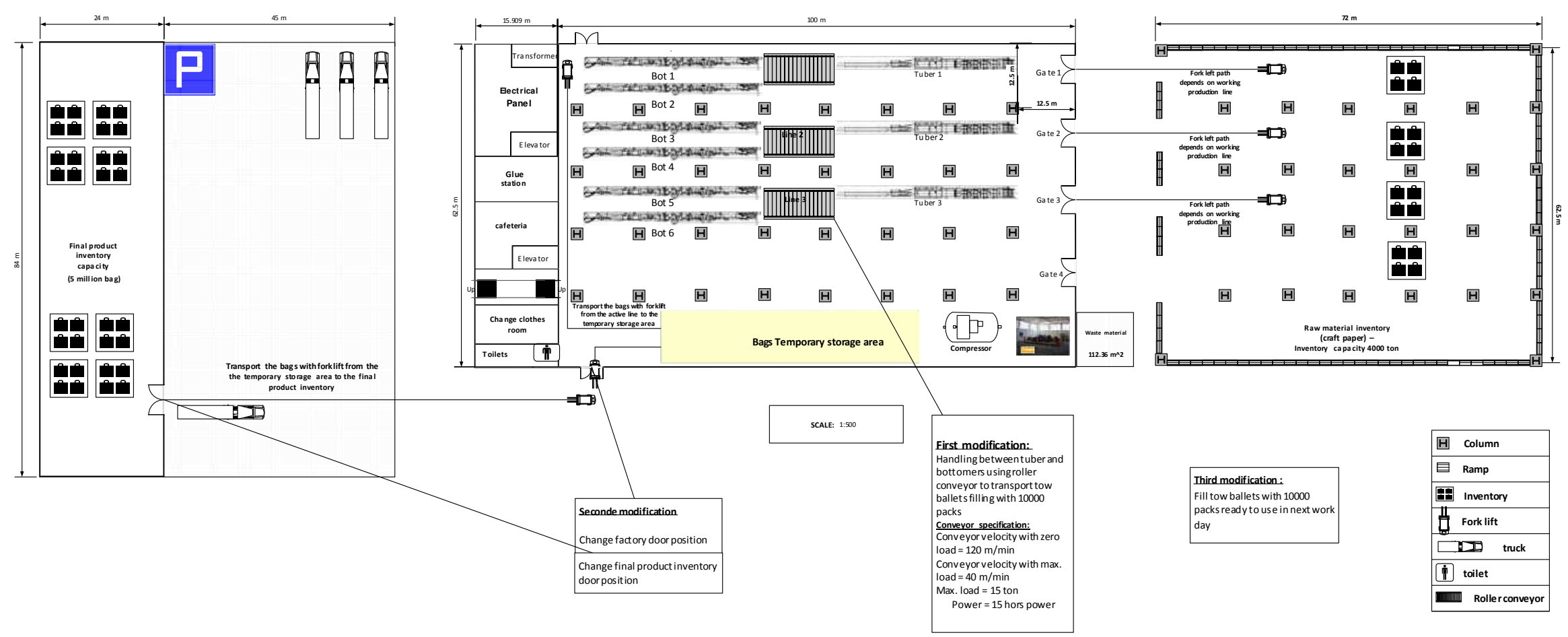

Fig. 14 Modified Layout of the Cement Sacks Factory 


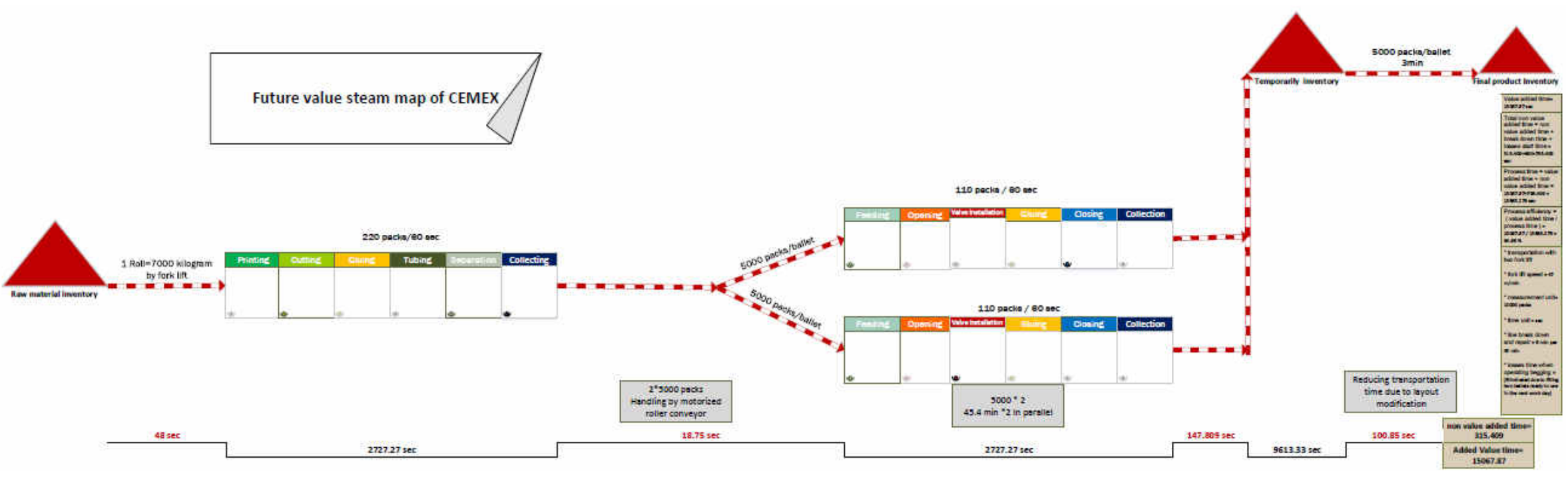

Fig. 15. Future VSM of the Cement Sacks Factory 
Mahmoud A. El-Sharief, Using value stream mapping for lean manufacturing implementation: cement sacks factory as an industrial case study, pp.2190 - 2212

\section{Conclusions}

Value stream mapping has proven to be an effective way to analyze a company's current production state and point out problem areas. The visual nature of value stream mapping, by combining information and material flow on one map, depicts how the two relate to the lead-time. By applying lean thinking and VSM technique in the Cement Sacks Factory case study, there are many benefits can be obtained as:

- Reduction in the handling cost which add to the production cost.

- Reduction in the forklift way from the temporary inventory to the final product inventory.

- Reaching the maximum benefit of the forklift.

- Reduction in the time required for handling between temporary and final product inventory to $100.85 \mathrm{sec}$ instead of $180 \mathrm{sec}$. This means that the reduction percentage is 56 .

There are many factors contributing to the lead-time, that is, order handling, planning, procurement, delivery, inspection, manufacturing, handling, picking, packing and delivery. This paper focuses on analysis of manufacturing data for reducing lead-time and addresses within Make and Plan. Future work can be carried out on design, order handling, delivery or reassembly since those are also important factors affecting production and lead-time in the company's operations.

\section{References}

[1] James P. Womack \& Daniel T. Jones, Lean Thinking, Free Press, New York, USA, 2003.

[2] T. MELTON, The Benefits of Lean Manufacturing: What Lean Thinking has to Offer the Process Industries, Chemical Engineering Research and Design, Vol. 83, 2005, pp. 662 673.

[3] Jim Womack \& Dan Jones, Learning to See Value Stream Mapping to Creat Value and Eliminate Muda, Brookline, massachusetts, USA, 1999.

[4] Ulf K. Teichgraeber, Maximilian de Bucourt, Applying value stream mapping techniques to eliminate non-value-added waste for the procurement of endovascular stents, European Journal of Radiology, Vol. 81, 2012, pp. 47- 52.

[5] H.J. Warnecke and M. Hueser, Lean Production, Int. J. Production Economics, Vol. 41 1995, pp. 37-43.

[6] Rachna Shah, and Peter T. Ward, Lean manufacturing: context, practice bundles, and performance, Journal of Operations Management, Vol. 21, 2003, pp. 129-149.

[7] Fawaz A. Abdulmalek and Jayant Rajgopal, Analyzing the benefits of lean manufacturing and value stream mapping via simulation: A process sector case study, Int. J. Production Economics, Vol. 107, 2007, pp. 223-236.

[8] Matthias Holweg, The genealogy of lean production, Journal of Operations Management, Vol. 25, 2007, pp. 420-437.

[9] Rachna Shah and Peter T. Ward, Defining and developing measures of lean production, Journal of Operations Management, Vol. 25, 2007, pp. 785-805.

Journal of Engineering Sciences, Assiut University, Faculty of Engineering, Vol. 41, No. 6, November, 2013,E-mail address: jes@aun.edu.eg 
Mahmoud A. El-Sharief, Using value stream mapping for lean manufacturing implementation: cement sacks factory as an industrial case study, pp. 2190 - 2212

استخدام خريطة تدفق المنتج والمعلومات في نظم التصنيع الرشيق: دراسةمصنع لإنتاج

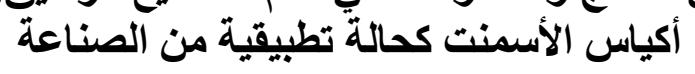

الملخص العربى:

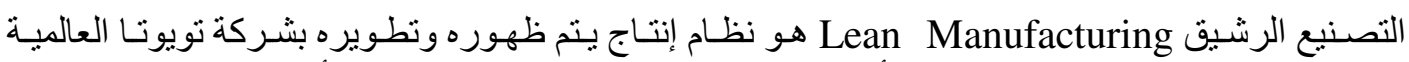

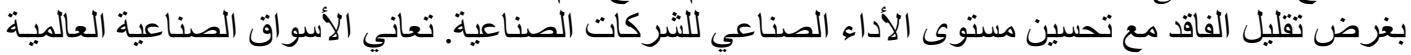

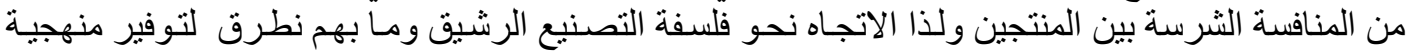

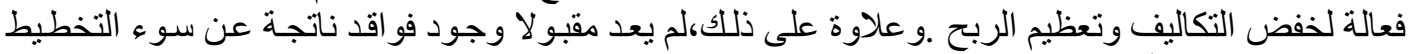

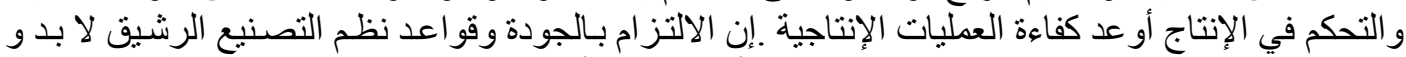

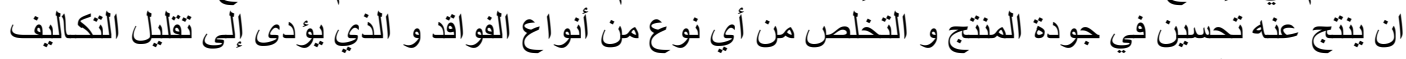

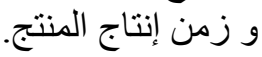

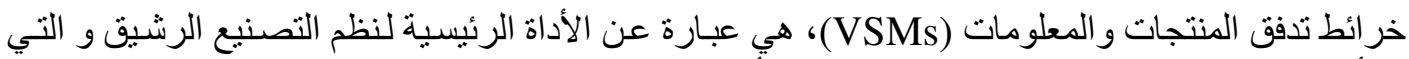

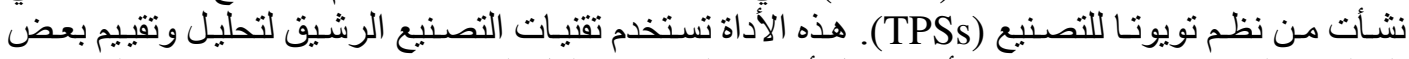

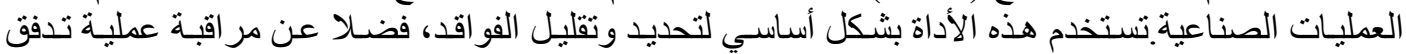

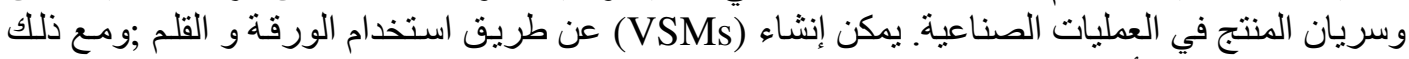

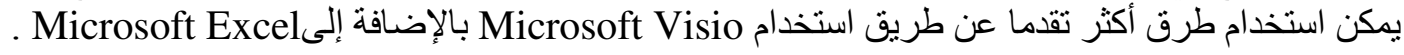

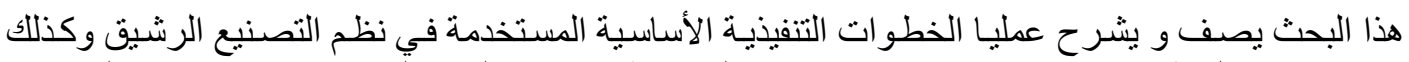

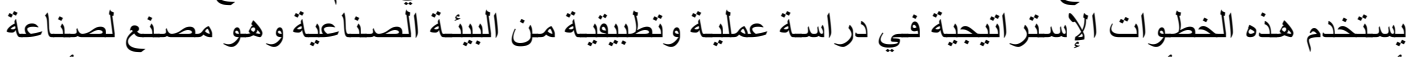

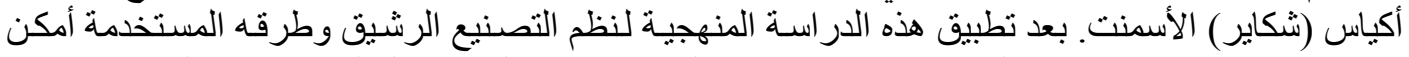

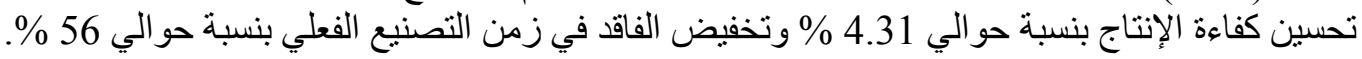

Journal of Engineering Sciences, Assiut University, Faculty of Engineering, Vol. 41, No. 6, November, 2013,E-mail address: jes@aun.edu.eg 